\title{
A Case of Vitamin D-Dependent Rickets Type 1A with a Novel Mutation in the Uzbek Population
}

\author{
Bahar Özcabı1, Feride Tahmiscioğlu Bucak1, Sevinç Jaferova1, Çiğdem Oruç1, Amra Adrovic1, \\ Serdar Ceylaner2, Oya Ercan1, Olcay Evliyaoğlu1 \\ 1/stanbul University Cerrahpaşa Faculty of Medicine, Department of Pediatric Endocrinology, Istanbul, Turkey \\ 2 Intergen Genetic Center and Yüksek Ihtisas University Faculty of Medicine, Department of Medical Genetics, Ankara, Turkey
}

\section{WHAT IS ALREADY KNOWN ON THIS TOPIC?}

Vitamin D-dependent rickets type IA (VDDR-IA) is a rare autosomal, recessively inherited disorder due to inactivating mutations in CYP27B I. It is characterized by early onset of rickets with hypocalcemia. In different ethnic groups, several mutations (homozygous or compound heterozygous) have been identified. Some studies reported that there is a good genotype-phenotype correlation in VDDR-IA. However, the patients carrying the mutations which can totally abolish the enzyme activity can have mild symptoms. Patients with VDDR-IA are usually treated with alfacalcidol or calcitriol.

\section{WHAT THIS STUDY ADDS?}

\section{ABSTRACT}

Vitamin D-dependent rickets type 1A (VDDR-1A) (Online Mendelian Inheritance in Man \#264700) is a rare, autosomal recessively inherited disorder due to inactivating mutations in CYP27B1. It is characterized by early onset of rickets with hypocalcemia. We aimed to describe the clinical and laboratory findings in a VDDR-1A case and to report a novel homozygote truncating mutation NM_000785.3 c.403C>T (p.0135*) in CYP27B1 which to our knowledge is the first described mutation in the Uzbek population. The patient was admitted with tetany at the age of 12 months. He was a healthy Uzbek boy until 9 months of age when he had a seizure due to hypocalcemia. Vitamin $\mathrm{D}$ treatment was given orally in Turkmenistan (no data available for dose and duration). The patient was the product of a consanguineous marriage. His brother had died with hypocalcemia and pneumonia. At physical examination, anthropometric measurements were within normal limits; he had caput quadratum, enlarged wrists, and carpopedal spasm. Blood calcium, phosphorus, alkaline phosphatase, and parathormone (PTH) levels were $5.9 \mathrm{mg} / \mathrm{dL}, 3.5 \mathrm{mg} / \mathrm{dL}, 987 \mathrm{IU} / \mathrm{L}$, and $182.8 \mathrm{pg} / \mathrm{mL}$ (12-72), respectively. Radiological findings included cupping and fraying of the radial and ulnar metaphyses. Renal ultrasound revealed nephrocalcinosis (grade 1). Despite high serum PTH and 25-hydroxyvitamin D3 levels, 1,25-dihydroxyvitamin D3 level was low, suggesting a diagnosis of VDDR-1A. The patient was treated with calcium carbonate and calcitriol. DNA sequencing revealed a novel homozygous mutation of NM_000785.3 c.403C >T (p.0135*) in CYP27B1. VDDR-1A is a rare disorder which needs to be considered even in countries where nutritional vitamin $\mathrm{D}$ deficiency is still common.

Keywords: 25-hydroxyvitamin D 1- $\alpha$ hydroxylase, the CYP27B1 gene, vitamin D-dependent rickets type 1, calcitriol

Conflict of interest: None declared

Received: 16.03 .2016

Accepted: 28.06 .2016

VDDR-IA is a rare disorder. We report here our clinical and treatment experience and a novel mutation in the CYP27B I gene which as far as we know is the first described mutation in the Uzbek population.

Address for Correspondence

Olcay Evliyaoğlu MD, Istanbul University Cerrahpaşa Faculty of Medicine, Department of Pediatric Endocrinology, Istanbul, Turkey

E-mail: olcayevliyaoglu@hotmail.com

This study was presented in "European Society for Pediatric Endocrinology" Dublin, Ireland, 20-22 September 2014.

OJournal of Clinical Research in Pediatric Endocrinology, Published by Galenos Publishing. 


\section{Introduction}

Vitamin D-dependent rickets type 1A (VDDR-1A) (Online Mendelian Inheritance in Man \#264700) is an inborn error of vitamin $\mathrm{D}$ metabolism involving defective conversion of 25-hydroxyvitamin D3 [25(OH)D3] to the active form 1,25-dihydroxyvitamin $\mathrm{D} 3\left[1,25(\mathrm{OH})_{2} \mathrm{D}_{3}\right]$ by the enzyme $25(\mathrm{OH})$ D-1-hydroxylase (1). This type of rickets is characterized by hypotonia, weakness, growth failure, and hypocalcemic seizures in early infancy $(1,2)$. The physical features, laboratory findings such as hypocalcemia with increased serum parathormone (PTH), and the radiological aspects of this condition mimic vitamin D deficiency; but typically, 25(OH)D3 levels are normal or elevated despite a low or low-normal serum 1,25(OH)2D3 level $(1,2,3,4)$. Due to blockage of $25(\mathrm{OH}) \mathrm{D}-1-\alpha$-hydroxylase, treatment consists of supplementation with calcium and active forms of vitamin $D(1,2)$.

VDDR-1A is an autosomal recessive disorder due to the mutation in the CYP27B1 gene encoding $25(\mathrm{OH}) \mathrm{D}-1-\alpha-$ hydroxylase, which catalyzes the hormonally regulated, rate limiting step in the bioactivation of vitamin $D(1,2,3,4,5,6,7,8,9$ $, 10,11,12,13,14,15,16,17,18,19,20,21)$. The CYP27B1 gene is mapped on chromosome 12q14 (4). In different ethnic groups, several mutations (homozygous or compound heterozygous) have been identified in patients with VDDR-1A $(3,5,7,8,9,10,11$, $12,13,14,15,16,17,18,19,20,21)$. In some ethnic groups, certain mutations are more frequent $(2,8,14,20)$. Some studies have reported that there is a good genotype-phenotype correlation in VDDR-1A (19). However, some patients carrying the mutations which can totally abolish the enzyme activity can present with mild symptoms. Additionally, partial remission during puberty may be observed more frequently in females than in males with the same mutation $(8,9,19)$. These points lead one to speculate that there are other factors which contribute to the variations in degree of severity of the clinical and laboratory findings.

Herein, we report the clinical and laboratory findings in a case of VDDR-1A with a novel mutation NM_000785.3 c.403C>T (p.Q135*) in CYP27B1 in a boy of Uzbek origin which as far as we know is the first mutation described in the Uzbek population.

\section{Case Report}

This male patient was admitted to our hospital with the clinical symptoms of tetany at the age of 12 months. He had his first seizure in Turkmenistan when he was 9 months old; at that time, he was found to be hypocalcemic which was attributed to vitamin $D$ deficiency as he had never received vitamin $D$ prophylaxis. Vitamin D treatment was given orally (no data are available regarding dose and duration of treatment). His parents brought the patient to Turkey in order to get a second opinion.

The patient was the product of a consanguineous marriage and both parents were of Uzbek origin. He teethed first at the age of 10 months. He had one healthy sister and an elder brother who had died at 12 months with a history of hypocalcemia and pneumonia.

Physical examination revealed carpopedal spasm and overactive tendon reflexes. Standard deviation score values

\begin{tabular}{|c|c|c|c|c|c|c|}
\hline Age (months) & $\begin{array}{l}\mathrm{Ca}(\mathrm{mg} / \mathrm{dL}) \\
(8.4-10.8)\end{array}$ & $\begin{array}{l}P(\mathrm{mg} / \mathrm{dL}) \\
(2.7-5.5)\end{array}$ & $\begin{array}{l}\text { ALP (IU/L) } \\
(60-525)\end{array}$ & $\begin{array}{l}\text { PTH }(\mathrm{pg} / \mathrm{mL}) \\
(12-72)\end{array}$ & Urinary $\mathrm{Ca} / \mathrm{Cr}$ ratio & Prescribed Treatment \\
\hline 12 & 5.9 & 3.5 & 987 & 182 & 0.08 & $\begin{array}{l}\text { Calcitriol } 2 \times 0.5 \mu \mathrm{g} / \mathrm{dose} \\
\text { Ca elementary } 65 \mathrm{mg} / \mathrm{kg} / \mathrm{d}\end{array}$ \\
\hline 15 & 8.8 & 6 & 653 & 226.8 & 0.26 & $\begin{array}{l}\text { Calcitriol } 3 \times 0.25 \mu \mathrm{g} / \mathrm{dose} \\
\text { Ca elementary } 65 \mathrm{mg} / \mathrm{kg} / \mathrm{d}\end{array}$ \\
\hline 18 & 9.3 & 6.2 & 374 & 77.5 & $\begin{array}{l}0.42 \\
(\mathrm{~N}:<0.4)\end{array}$ & $\begin{array}{l}\text { Calcitriol } 3 \times 0.25 \mu \mathrm{g} / \mathrm{dose} \\
\text { Ca elementary } 50 \mathrm{mg} / \mathrm{kg} / \mathrm{d}\end{array}$ \\
\hline 21 & 10.4 & 6.8 & 243 & 6.81 & $\begin{array}{l}0.54 \\
(\mathrm{~N}:<0.4)\end{array}$ & $\begin{array}{l}\text { Calcitriol } 2 \times 0.5 \mu \mathrm{g} / \mathrm{dose} \mathrm{e}^{* *} \\
\text { Ca elementary } 28 \mathrm{mg} / \mathrm{kg} / \mathrm{d}\end{array}$ \\
\hline 24 & 10.6 & 5.4 & 255 & 3.72 & $\begin{array}{l}0.99 \\
(\mathrm{~N}:<0.4)\end{array}$ & $\begin{array}{l}\text { Calcitriol } 2 \times 0.25 \mu \mathrm{g} / \text { dose } \\
\text { Ca supplementation was stopped }\end{array}$ \\
\hline 31 & 9.6 & 5.7 & 266 & 69.91 & $\begin{array}{l}0.1 \\
(\mathrm{~N}:<0,38)\end{array}$ & Calcitriol $2 \times 0.25 \mu \mathrm{g} /$ dose \\
\hline 35 & 9.3 & 5.2 & 262 & 46.7 & $\begin{array}{l}0.1 \\
(\mathrm{~N}:<0,38)\end{array}$ & Calcitriol $2 \times 0.25 \mu \mathrm{g} /$ dose \\
\hline 43 & 10.4 & 6.3 & 318 & 26.55 & $\begin{array}{l}0.36 \\
(\mathrm{~N}:<0,38)\end{array}$ & Calcitriol $1 \times 0.25 \mu \mathrm{g} /$ dose \\
\hline
\end{tabular}


for height, weight, and head circumference were -1.83, -1.02, and 1.64 , respectively. Caput quadratum and enlargement of the wrists were distinct. He had two central incisors. Blood calcium, phosphorus, and alkaline phosphatase levels were 5.9 $\mathrm{mg} / \mathrm{dL}(1.4 \mathrm{mmol} / \mathrm{L}), 3.5 \mathrm{mg} / \mathrm{dL}(1.15 \mathrm{mmol} / \mathrm{L})$, and $987 \mathrm{IU} / \mathrm{L}$, respectively. Urine calcium/creatinine ratio was $0.006[\mathrm{~N}:<0.4$ (22)] in spot sampling. Serum levels of PTH (182.8 pg/mL, N:12$72)$ and $25(\mathrm{OH}) \mathrm{D} 3$ levels $(125 \mu \mathrm{g} / \mathrm{L})$ were high and $1,25(\mathrm{OH})_{2} \mathrm{D}_{3}$ level (8.5 pg/mL, N:15-90 pg/mL) was low (Table 1). No abnormalities of acid-base metabolism and renal dysfunction were detected. Radiological findings included cupping and fraying of the metaphyseal regions of the radius and ulna. Renal ultrasonography revealed nephrocalcinosis of grade 1 (Figure 1). Clinical and laboratory findings suggested a diagnosis of VDDR1A. Calcium carbonate (elementary calcium $75 \mathrm{mEq} / \mathrm{kg} / \mathrm{d}$ ) and calcitriol $(1 \mu \mathrm{g} / \mathrm{d})$ treatments were started to which the patient responded well by increasing his serum Ca level to the normal range. Laboratory findings and treatment of the patient in the follow-up are summarized in Table 1. Bone lesions were almost healed at the second month of the treatment (Figure 2).

A clinical diagnosis of VDDR-1A was made and a genetic analysis was performed to confirm the diagnosis. Sequence analysis of all coding regions and exon-intron boundaries were done by in-house designed primers using Sanger sequencing technique performed on $\mathrm{ABI}$ Prism 3130 GeneticAnalyser (Applied Biosystems, Inc., Foster City, CA, ABD) capillary electrophoresis system with standard protocols by using Big Dye Terminator cycle sequencing kit (Applied Biosystems, Inc., Foster City, CA, ABD) and a novel mutation NM_000785.3 (CYP27B1): c.403C>T (p.Q135*) was described (Figure 3).

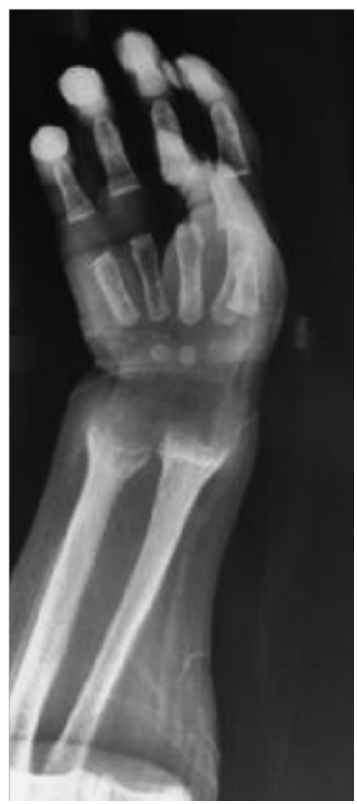

Figure 1. Radiological findings before treatment: cupping and fraying of the metaphyseal regions of ulna and radius (parents consented to the publication of these photos)
Mutation taster predicts this variant as a disease-causing mutation. This variant was screened in 200 healthy people and no mutation was detected in any. Other members of the patient's family (mother, father, and elderly sister) were heterozygous carriers for this novel mutation.

\section{Discussion}

VDDR-1A is an autosomal recessive disorder due to an inactivating mutation in the CYP27B1 gene on chromosome $12 q 14 \quad(1,2,3,4,5,6,7,8,9,10,11,12,13,14,15,16,17,18,19$, 20,21). The CYP27B1 gene encodes $25(\mathrm{OH}) \mathrm{D}-1-\alpha$-hydroxylase which catalyzes the hormonally regulated, rate limiting step

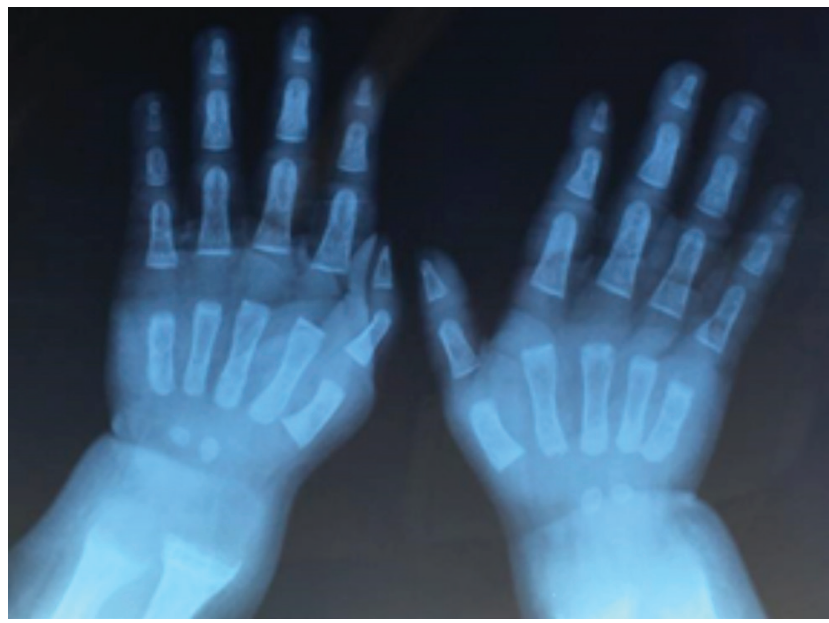

Figure 2. Radiological findings at the second month of the treatment: bone lesions were almost healed (parents consented to the publication of these photos)

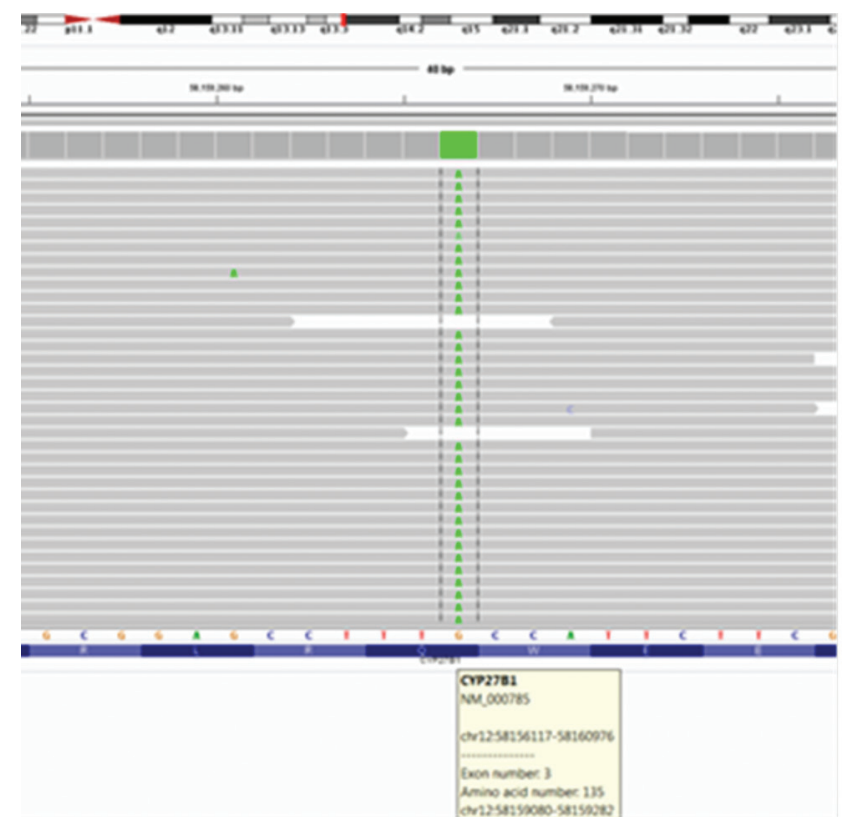

Figure 3. Novel mutation p. $0135^{*}$ (c.403 C>T) in the CYP27B1 gene 
Özcabı B et al.

Novel Mutation in the CYP27B1 Gene

\begin{tabular}{|c|c|c|c|c|c|c|c|c|c|}
\hline Mutation & Age & Clinical features & Ca mg/dL & $\mathrm{P} \mathrm{mg} / \mathrm{dL}$ & ALP IU/L & $\begin{array}{l}25(\mathrm{OH}) D \\
\mu \mathrm{g} / \mathrm{L}\end{array}$ & $\begin{array}{l}1,25(\mathrm{OH})_{2} \mathrm{D}_{3} \\
\mathrm{pg} / \mathrm{mL}\end{array}$ & $\begin{array}{l}\text { PTH pg/ } \\
\mathrm{mL}\end{array}$ & Reference \\
\hline $\begin{array}{l}\text { Compound } \\
\text { heterozygous } \\
\text { c. } 1166 \mathrm{G}>\mathrm{A}\end{array}$ & 13 months & NA & $6.2(\downarrow)$ & $3.7(\downarrow)$ & $1042(\uparrow)$ & $103(\uparrow)$ & $55^{*}$ & 171 & 8 \\
\hline $\begin{array}{l}\text { Homozygous } \\
\text { 1319-1325dup } \\
\text { СССАССС }\end{array}$ & 11.5 years & NA & $7.6(\downarrow)$ & 5.5 & $1730(\uparrow)$ & $304(\uparrow)$ & 44 & NA & 8 \\
\hline $\begin{array}{l}\text { Homozygous } \\
\text { 1319-1325dup } \\
\text { СССАССС }\end{array}$ & 4 months & $\begin{array}{l}\text { Hypocalcemic } \\
\text { Seizure }\end{array}$ & $6(\downarrow)$ & $3.3(\downarrow)$ & $443(\uparrow)$ & 32 & UD & $191.8(\uparrow)$ & 19 \\
\hline $\begin{array}{l}\text { Homozygous } \\
\text { 1319-1325dup } \\
\text { СССАССС }\end{array}$ & 4 month & $\begin{array}{l}\text { Hypocalcemic } \\
\text { Seizure }\end{array}$ & $6(\downarrow)$ & 5.4 & $1320(\uparrow)$ & $51.3(\uparrow)$ & NA & $102.6(\uparrow)$ & 19 \\
\hline $\begin{array}{l}\text { Homozygous } \\
\text { 1319-1325dup } \\
\text { СССАССС }\end{array}$ & 19 month & Failure to walk & 9.1 & $1.7(\downarrow)$ & $5254(\uparrow)$ & 41.7 & UD & $516.7(\uparrow)$ & 19 \\
\hline $\begin{array}{l}\text { Homozygous } \\
\text { 1319-1325dup } \\
\text { СССАССС }\end{array}$ & 18 months & Failure to walk & 9.1 & $1.61(\downarrow)$ & $4441(\uparrow)$ & 56 & UD & $340(\uparrow)$ & 19 \\
\hline $\begin{array}{l}\text { Compound } \\
\text { heterozygous } \\
\text { c. } 1079 \mathrm{C}>\mathrm{A}\end{array}$ & 14 months & Bowed legs & $7.5(\downarrow)$ & $2.39(\downarrow)$ & $5546(\uparrow)$ & $108.2(\uparrow)$ & $14(\downarrow)$ & $376(\uparrow)$ & 19 \\
\hline $\begin{array}{l}\text { Homozygous } \\
195+2 T>G\end{array}$ & 18 months & $\begin{array}{l}\text { Bowed legs } \\
\text { Severe bone } \\
\text { deformities } \\
\text { Short stature }\end{array}$ & $6.8(\downarrow)$ & 3.5 & $496(\uparrow)$ & $85.3(\uparrow)$ & $14.2(\downarrow)$ & $268.8(\uparrow)$ & 19 \\
\hline $\begin{array}{l}\text { Homozygous } \\
195+2 T>G\end{array}$ & 18 months & \begin{tabular}{|l} 
Bowed legs \\
Severe bone \\
deformities \\
Short stature \\
\end{tabular} & $6.1(\downarrow)$ & 3.5 & $2889(\uparrow)$ & $142.2(\uparrow)$ & $30^{*}$ & $176.6(\uparrow)$ & 19 \\
\hline $\begin{array}{l}\text { Homozygous } \\
195+2 T>G\end{array}$ & 12 months & $\begin{array}{l}\text { Failure to thrive } \\
\text { Inability to walk }\end{array}$ & 8.9 & $1.8(\downarrow)$ & $2190(\uparrow)$ & 44 & $4.5(\downarrow)$ & $938(\uparrow)$ & 20 \\
\hline $\begin{array}{l}\text { Homozygous } \\
195+2 T>G\end{array}$ & 26 months & $\begin{array}{l}\text { Failure to thrive } \\
\text { Inability to walk } \\
\end{array}$ & $7.1(\downarrow)$ & 2.7 & $1850(\uparrow)$ & 35 & $<2.1(\downarrow)$ & $466(\uparrow)$ & 20 \\
\hline $\begin{array}{l}\text { Homozygous } \\
195+2 T>G\end{array}$ & 21 months & $\begin{array}{l}\text { Failure to thrive } \\
\text { Fractures }\end{array}$ & 8.6 & 2.5 & $1825(\uparrow)$ & $238(\uparrow)$ & $14(\downarrow)$ & $728(\uparrow)$ & 20 \\
\hline $\begin{array}{l}\text { Homozygous } \\
\text { c.1022-1037del16 }\end{array}$ & 16 months & Inability to walk & 8.5 & 3.4 & $1802(\uparrow)$ & 40.44 & $3.2(\downarrow)$ & $703.8(\uparrow)$ & 20 \\
\hline $\begin{array}{l}\text { Homozygous } \\
\text { c.1022-1037del16 }\end{array}$ & 17 months & $\begin{array}{l}\text { Failure to thrive } \\
\text { Inability to walk }\end{array}$ & 8.9 & $1.94(\downarrow)$ & $1523(\uparrow)$ & $189(\uparrow)$ & $9.1(\downarrow)$ & $560(\uparrow)$ & 20 \\
\hline $\begin{array}{l}\text { Homozygous } \\
1215+2 T>A\end{array}$ & 21 months & Inability to walk & $6.5(\downarrow)$ & 2.9 & $1622(\uparrow)$ & $125(\uparrow)$ & 25 & 319 & 20 \\
\hline $\begin{array}{l}\text { Homozygous } \\
1215+2 T>A\end{array}$ & 13 months & $\begin{array}{l}\text { Failure to thrive } \\
\text { Fractures } \\
\text { Blue sclera }\end{array}$ & $4.2(\downarrow)$ & 3.5 & $684(\uparrow)$ & 40 & NA & 284 & 20 \\
\hline $\begin{array}{l}\text { Homozygous } \\
\text { c.934_935delAC }\end{array}$ & 13 months & $\begin{array}{l}\text { Hypocalcemic } \\
\text { seizure }\end{array}$ & $6.5(\downarrow)$ & 3.9 & $1100(\uparrow)$ & 54 & $13(\downarrow)$ & $555(\uparrow)$ & 20 \\
\hline $\begin{array}{l}\text { Homozygous } \\
\text { c. } 403 \mathrm{C}>\mathrm{T}\end{array}$ & 12 months & $\begin{array}{l}\text { Hypocalcemic } \\
\text { seizure }\end{array}$ & $5.9(\downarrow)$ & 3.5 & $987(\uparrow)$ & $125(\uparrow)$ & $8.5(\downarrow)$ & $182(\uparrow)$ & $* *$ \\
\hline
\end{tabular}


in the bioactivation of vitamin $D(1,2,3,4)$. Due to blockage of this enzyme activity, normal or elevated 25(OH)D3 level, despite low or low-normal serum $1,25(\mathrm{OH})_{2} \mathrm{D}_{3}$, is prominent in VDDR-1A which mimics clinically and radiologically vitamin $D$ deficiency $(1,2,3,5)$. There are no studies on the incidence of vitamin $D$ deficiency in Turkmenistan where our patient lives, but there are reports from countries such as Turkey where nutritional rickets is still encountered (23). Our patient did not respond to vitamin $\mathrm{D}$ supplementation, but he was born to consanguineous parents and had an elder brother who was reported to have died of hypocalcemia and pneumonia. These 3 points raised suspicion and the low 1,25(OH) 2 D levels concomitant with high $25(\mathrm{OH}) \mathrm{D} 3$ levels suggested a diagnosis of VDDR-1A, which was confirmed by identification of a novel homozygous mutation of p.Q135* (c.403 C>T) in the CYP27B1.

So far, more than 50 mutations have been identified in patients with VDDR-1A from various ethnic groups $(3,5,6,7,8$, $9,10,11,12,13,14,15,16,17,18,19,20,21)$. The Uzbek population is a Turkic people in Central Asia. Mutations, clinical and laboratory features of the previously reported cases with mutations in the Turkish population and the findings of our patient (presented in Table 2) indicate that age at presentation and clinical/laboratory findings show variations, even in patients with the same mutation. In our patient, the main clinical sign was hypocalcemic seizures. Also, he had hypocalcemia without hypophosphatemia. We identified a novel nonsense mutation c.403C>T (p.Q135*) in exon 3. Our patient was homozygous and other family members (mother, father, sister) were heterozygous for this novel mutation. As this mutation results in a truncating protein, it probably causes severe inactivation of the enzyme. As far as we know, this is the first mutation reported in the Uzbek population.

Patients with VDDR-1A are usually treated with alfacalcidol or calcitriol. Edouard et al (24) reported short- and long-term outcomes of calcitriol treatment in their patients. Calcitriol was started at a dose of $1.0 \mu \mathrm{g} / \mathrm{d}$, given in two doses of 0.5 $\mu \mathrm{g}$. Subsequently, the calcitriol dose was modified according to the results of biochemical analyses. Normal calcium and PTH levels without hypercalciuria were tried to be achieved. The median daily calcitriol dose was reduced to $0.50 \mu \mathrm{g} / \mathrm{d}$ (range 0.2-1.0 $\mu \mathrm{g}$ ) after 3 months, to $0.25 \mu \mathrm{g} / \mathrm{d}$ (range 0.1-1.0 $\mu \mathrm{g})$ after 1 year, and to $0.25 \mu \mathrm{g} / \mathrm{d}$ (range $0.1-0.5 \mu \mathrm{g}$ ) after two years of the treatment. Our patient was also treated with calcium supplementation and calcitriol of $1.0 \mu \mathrm{g} / \mathrm{d}$, given in two doses. At the second month of the treatment, skeletal deformities were almost healed (Figure 2) and renal ultrasound was normal without nephrocalcinosis; but at the third month of treatment, serum phosphorus level increased to the upper normal limit and hypercalciuria was detected. The calcitriol dose was decreased to $0.75 \mu \mathrm{g} / \mathrm{d}$ given in three doses. At the ninth month of the follow-up, as calcitriol treatment was used in a dose higher than that prescribed $(3 \times 0.5 \mu \mathrm{g} / \mathrm{dose}$ instead of $3 \times 0.25 \mu \mathrm{g} /$ dose), serum PTH level decreased below normal ranges and urinary analysis revealed hypercalciuria. Over the next 13 months, the calcitriol dose was decreased to $0.5 \mu \mathrm{g} / \mathrm{d}$, while the calcium supplementation was withdrawn at the third month of this tapering process. At the third year of follow-up, our patient was receiving $0.25 \mu \mathrm{g} / \mathrm{d}$ of calcitriol. His growth was normal, normocalcemia without hyperphosphatemia or nephrocalcinosis had been achieved (Table 1).

Although a rare disorder, VDDR-1A must be considered even in countries where vitamin D deficiency is still common. Genetic analyses are beneficial for early diagnosis of probable familial cases. The novel mutation NM_000785.3 c.403C>T $($ p.Q135*) causes a truncating protein probably associated with severe inactivity. We believe that this patient is the first case with this mutation reported in the Uzbek population.

\section{Ethics}

Informed Consent: It was taken. Peer-review: Externally peer-reviewed.

\section{Authorship Contributions}

Concept: Bahar Özcabı, Feride Tahmiscioğlu Bucak, Sevinç Jaferova, Çiğdem Oruç, Amra Adrovic, Serdar Ceylaner, Oya Ercan, Olcay Evliyaoğlu, Design: Bahar Özcabı, Feride Tahmiscioğlu Bucak, Sevinç Jaferova, Çiğdem Oruç, Amra Adrovic, Serdar Ceylaner, Oya Ercan, Olcay Evliyaoğlu, Data Collection or Processing: Bahar Özcabı, Feride Tahmiscioğlu Bucak, Sevinç Jaferova, Çiğdem Oruç, Amra Adrovic, Serdar Ceylaner, Oya Ercan, Olcay Evliyaoğlu, Analysis or Interpretation: Bahar Özcabı, Feride Tahmiscioğlu Bucak, Sevinç Jaferova, Çiğdem Oruç, Amra Adrovic, Serdar Ceylaner, Oya Ercan, Olcay Evliyaoğlu, Literature Search: Bahar Özcabı, Feride Tahmiscioğlu Bucak, Sevinç Jaferova, Çiğdem Oruç, Amra Adrovic, Serdar Ceylaner, Oya Ercan, Olcay Evliyaoğlu, Writing: Bahar Özcabı, Feride Tahmiscioğlu Bucak, Sevinç Jaferova, Çiğdem Oruç, Amra Adrovic, Serdar Ceylaner, Oya Ercan, Olcay Evliyaoğlu,

Financial Disclosure: The authors declared that this study received no financial support.

\section{References}

1. Fraser $D$, Kooh SW, Kind HP, Holick MF, Tanaka $Y$, DeLuca HF. Pathogenesis of hereditary vitamin-D-dependent rickets. An inborn error of vitamin $\mathrm{D}$ metabolism involving defective conversion of 25-hydroxyvitamin D to 1 alpha,25-dihydroxyvitamin D. N Engl J Med 1973;289:817-822.

2. Miller $\mathrm{WL}$, Portale AA. Vitamin D 1 alpha-hydroxylase. Trends Endocrinol Metab 2000;11:315-319.

3. Kitanaka S, Takeyama K, Murayama A, Sato T, Okumura K, Nogami M, Hasegawa Y, Niimi H, Yanagisawa J, Tanaka T, Kato S. Inactivating mutations in the 25-hydroxyvitamin D3 1alpha-hydroxylase gene in patients with pseudovitamin D-deficiency rickets. N Engl J Med 1998;338:653-661.

4. Labuda M, Morgan K, Glorieux FH. Mapping autosomal recessive vitamin $D$ dependency type I to chromosome $12 q 14$ by linkage analysis. Am J Hum Genet 1990;47:28-36. 
5. Babiker AM, Al Gadi I, Al-Jurayyan NA, Al Nemri AM, Al Haboob AA, Al Boukai AA, Al Zahrani A, Habib HA. A novel pathogenic mutation of the CYP27B1 gene in a patient with vitamin D-dependent rickets type 1: a case report. BMC Res Notes 2014;7:783.

6. St-Arnaud R, Messerlian S, Moir JM, Omdahl JL, Glorieux FH. The 25-hydroxyvitamin D 1-alpha-hydroxylase gene maps to the pseudovitamin D-deficiency rickets (PDDR) disease locus. J Bone Miner Res 1997;12:1552-1559.

7. Fu GK, Lin D, Zhang MY, Bikle DD, Shackleton CH, Miller WL, Portale AA. Cloning of human 25-hydroxyvitamin D-1 alpha-hydroxylase and mutations causing vitamin D-dependent rickets type 1. Mol Endocrinol 1997;11:1961-1970.

8. Wang JT, Lin CJ, Burridge SM, Fu GK, Labuda M, Portale AA, Miller WL. Genetics of vitamin D 1alpha-hydroxylase deficiency in 17 families. Am J Hum Genet 1998;63:1694-1702.

9. Kitanaka S, Murayama A, Sakaki T, Inouye K, Seino Y, Fukumoto $S$, Shima M, Yukizane S, Takayanagi M, Niimi H, Takeyama K, Kato S. No enzyme activity of 25-hydroxyvitamin D3 1alpha-hydroxylase gene product in pseudovitamin $\mathrm{D}$ deficiency rickets, including that with mild clinical manifestation. J Clin Endocrinol Metab 1999;84:4111-4117.

10. Wang $X$, Zhang MY, Miller WL, Portale AA. Novel gene mutations in patients with 1alpha-hydroxylase deficiency that confer partial enzyme activity in vitro. J Clin Endocrinol Metab 2002;87:2424-2430.

11. Smith SJ, Rucka AK, Berry JL, Davies M, Mylchreest S, Paterson CR, Heath DA, Tassabehji M, Read AP, Mee AP, Mawer EB. Novel mutations in the 1alpha-hydroxylase (P450c1) gene in three families with pseudovitamin D-deficiency rickets resulting in loss of functional enzyme activity in blood-derived macrophages. J Bone Miner Res 1999;14:730-739.

12. Yoshida T, Monkawa T, Tenenhouse HS, Goodyer P, Shinki T, Suda T, Wakino S, Hayashi M, Saruta T. Two novel 1alpha-hydroxylase mutations in French-Canadians with vitamin $D$ dependency rickets type 11. Kidney Int 1998;54:1437-1443.

13. Porcu L, Meloni A, Casula L, Asunis I, Marini MG, Cao A, Moi P. A novel splicing defect (IVS6+1G>T) in a patient with pseudovitamin D deficiency rickets. J Endocrinol Invest 2002;25:557-560.

14. Cao L, Liu F, Wang Y, Ma J, Wang S, Wang L, Zhang Y, Chen C, Luo $Y, M a H$. Novel vitamin D 1alpha-hydroxylase gene mutations in a Chinese vitamin-D-dependent rickets type I patient. J Genet 2011;90:339-342.

15. Sovik O, Boman H. Co-occurrence of vitamin D-dependent rickets type 1 and phenylketonuria. Acta Paediatr 2008;97:665-667.

16. Durmaz E, Zou M, Al-Rijjal RA, Bircan I, Akcurin S, Meyer B, Shi Y. Clinical and genetic analysis of patients with vitamin D-dependent rickets type 1A. Clin Endocrinol (Oxf) 2012;77:363-369.

17. Demir K, Kattan WE, Zou M, Durmaz E, BinEssa H, Nalbantoglu O, Al-Rijjal RA, Meyer B, Ozkan B, Shi Y. Novel CYP27B1 Gene Mutations in Patients with Vitamin D-Dependent Rickets Type 1A. PLoS One 2015;10:e0131376.

18. Alzahrani AS, Zou M, Baitei EY, Alshaikh OM, Al-Rijjal RA, Meyer BF, Shi Y. A novel G102E mutation of CYP27B1 in a large family with vitamin D-dependent rickets type 1. J Clin Endocrinol Metab 2010;95:4176-4183. Epub 2010 Jun 9

19. Yamamoto K, Uchida E, Urushino N, Sakaki T, Kagawa N, Sawada N, Kamakura M, Kato S, Inouye K, Yamada S. Identification of the amino acid residue of CYP27B1 responsible for binding of 25-hydroxyvitamin D3 whose mutation causes vitamin D-dependent rickets type 1. J Biol Chem 2005;280:30511-30516. Epub 2005 Jun 22

20. Kim CJ, Kaplan LE, Perwad F, Huang N, Sharma A, Choi Y, Miller WL, Portale AA. Vitamin D 1alpha-hydroxylase gene mutations in patients with 1alpha-hydroxylase deficiency. J Clin Endocrinol Metab 2007:92:3177-3182. Epub 2007 May 8

21. Hu WW, Ke YH, He JW, Fu WZ, Wang C, Zhang H, Yue H, Gu JM, Zhang ZL. A novel compound mutation of CYP27B1 in a Chinese family with vitamin D-dependent rickets type 1A. J Pediatr Endocrinol Metab 2014;27:335-341.

22. Vachvanichsanong P, Lebel L, Moore ES. Urinary calcium excretion in healthy Thai children. Pediatr Nephrol 2000;14:847-850.

23. Tezer H, Siklar Z, Dallar Y, Dogankoc S. Early and severe presentation of vitamin $D$ deficiency and nutritional rickets among hospitalized infants and the effective factors. Turk J Pediatr 2009;51:110-115.

24. Edouard T, Alos N, Chabot G, Roughley P, Glorieux FH, Rauch F. Shortand long-term outcome of patients with pseudo-vitamin $D$ deficiency rickets treated with calcitriol. J Clin Endocrinol Metab 2011;96:82-89. Epub 2010 Oct 6 